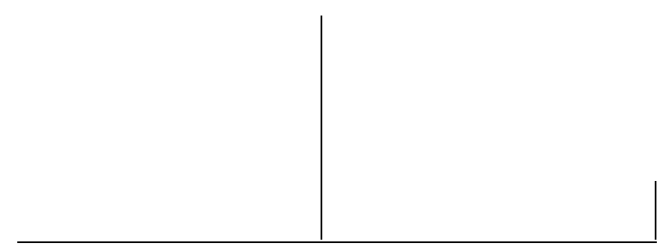

Rev. Latinoam. Psicopat. Fund., IX, 2, 245-262

\title{
Do delirante ao ficcional: um estudo sobre a situação psicanalítica em um caso de paranóia
}

\author{
Joyce Marly Gonçalves Freire
}

\begin{abstract}
Este ensaio é um estudo psicanalítico a respeito de Lia, paranóica, artista em tempo integral, que, ao tecer suas estórias, viu a linha que separa a ficção da realidade ser esfumaçada em seu ato de escrita. Escritora de romances $e$ poesias, Lia também pinta sobre quaisquer suportes que se lhe apresentam. Consideraremos que sua paranóia não pode ser separada de sua produção literária e gráfica, pois elas estão entranhadas umas nas outras. Assim, o tratamento psicanalítico realizado com essa paciente decorreu precisamente daquilo que constitui sua paranóia: sua produção escrita e artística. No desenrolar da situação analítica sua escrita é transformada pela leitura de um outro fora dela e, nesse nicho, Lia pôde construir uma forma diferente de subjetivação.
\end{abstract}

Palavras-chave: Escrita, leitura, paranóia, psicanálise 


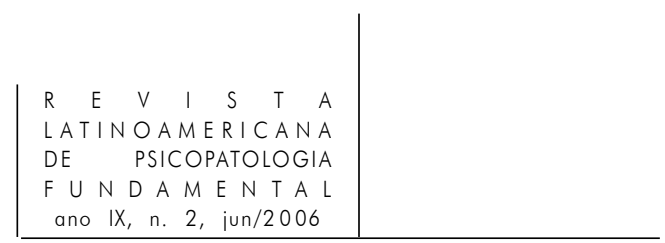

\footnotetext{
Fantasia caprichosa, dourada! Aproxima-te de um de nós, lisonjeira, com flagrante amizade, e o transformas no mais feliz dos loucos, o poeta; como um inimigo atacas e o transformas no mais lamentável dos poetas: o louco

Schnitzler, Contos de amor e morte, p. 44.
}

Com estas palavras Schnitzler (1987) encerra um de seus contos de amor e morte. Em estreita amizade com suas sombras, o senhor Ypsilon fora arrebatado pela paixão por Türkisa, "a mais graciosa das criaturas que jamais fora vista por homens ou por deuses”, personagem que brotara pelo encantamento com sua própria fantasia. Pelos jogos dessa mesma fantasia, quando sua criatura volta à penumbra e submerge no nada, Ypsilon não pode mais continuar a viver. Enlouqueceu e morreu.

Neste ensaio, apresentaremos um estudo psicanalítico a respeito de Lia, como a nomearemos, paranóica, artista em tempo integral que, como o Sr. Ypsilon, esfumaçou a linha que separa a ficção da realidade. Escritora de romances e poesias Lia também pinta sobre quaisquer suportes que se lhe apresentam. Consideraremos que sua paranóia não pode ser separada de sua produção literária e gráfica, pois elas estão entranhadas umas nas outras. Assim, o tratamento psicanalítico realizado com essa paciente decorreu precisamente daquilo que constitui sua paranóia: sua produção escrita e artística. No desenrolar da situação analítica sua escrita é transformada pela leitura de um outro fora dela e, nesse nicho, Lia pôde construir uma forma diferente de subjetivação.

\section{O lugar da escrita no tratamento psicanalítico}

... as palavras numa página dão coerência ao mundo

Manguel, 2000, p. 13

As produções literárias estão fortemente presentes na paranóia e dão a ela uma unidade que a separa da esquizofrenia. A esse respeito, Lacan (1953) escreve que: "As produções discursivas que caracterizam o registro das paranóias desenvolvem-se com toda a força, aliás, a maior parte do tempo, em produções literárias, no sentido em que literárias quer dizer simplesmente folhas de papel 


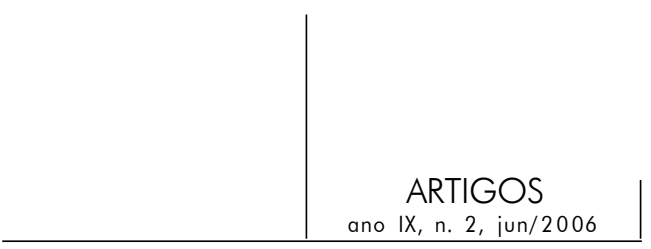

cobertas com escrita” (p. 93). Na paranóia, o sujeito é impulsionado a escrever seu delírio em um substrato, como se aí, nas letras sulcadas no papel, pudesse encontrar um método para sua loucura e, assim, dar uma certa sistematização para a incoerência de seu mundo delirante. Literalmente, o paranóico se inscreve nas folhas que escreve.

O caso mais clássico que temos sobre a escrita e a paranóia é o do “Presidente Schreber”, cujas memórias foram publicadas no começo do século passado e, calcado nestes relatos autobiográficos, Freud (1911) fez uma longa reflexão psicanalítica sobre esta patologia. A loucura de Schreber o levara a ser destituído de seu cargo de presidente da Corte de Apelação de Dresden e a algumas internações em sanatórios. Seus escritos sobre sua doença visavam o reconhecimento de sua pessoa pelas autoridades civis e constituíam sua tentativa de recuperar seu lugar na vida social.

Em seu seminário sobre "As psicoses”, grande parte dele dedicado ao estudo dos escritos desse famoso paranóico que foi Schreber, Lacan (1953), dirigindo-se ao público que o escutava semanalmente, dizia que esses testemunhos delirantes do paranóico - no caso de Schreber, um testemunho não só escrito, mas publicado -, escancaram uma contradição, pois, a despeito de o louco parecer à primeira vista apartado dos outros, como se seu mundo lhe fosse suficiente, o ensejo em ser publicado preenche uma "necessidade de reconhecimento". (p. 94)

Mas, o interesse de Lacan pela paranóia e pela escrita já estava presente vinte anos antes de seu seminário sobre as psicoses. Em 1932, a partir de entrevistas com uma paciente - o caso Aimée - e seus familiares e de observações sobre as produções literárias da mesma, ele escreve sua tese de doutorado sobre a relação entre a paranóia e a personalidade. A despeito de tê-la acompanhado por mais de um ano no hospital em que ela se encontrava internada, o interesse do jovem psiquiatra pelos escritos de Aimée voltou-se para o que eles poderiam revelar do ponto de vista clínico a respeito "do estado mental da doente na época de sua composição; mas, sobretudo, permitem que possamos apreender ao vivo certos traços de sua personalidade” (Lacan, 1987, p. 175), constituindo assim um material precioso para o estudo das relações do delírio e da personalidade desta paciente.

Winnicott (1971), em sua clínica infantil, usava não propriamente a escrita, mas os rabiscos e traços no papel, dos quais a escrita deriva como instrumento clínico. Através do “jogo dos rabiscos” (squiggle game), cujas impressões diziam muito sobre o mundo interno e desconhecido da criança, era possível estabelecer um forte vínculo terapêutico com o analista (p. 32). No caso de um pequeno paciente de Winnicott, esses rabiscos revelaram toda a dificuldade da criança em suas experiências de separação da mãe e sempre remetiam à imagem gráfica de 


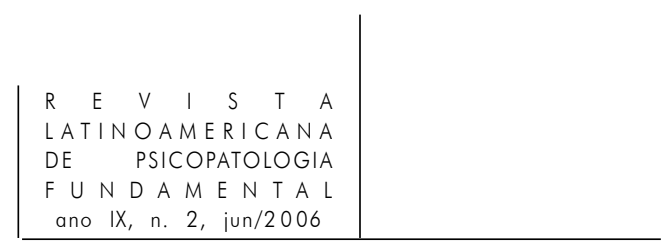

laço, chicote, cordão, nó etc., traços esses que deixavam a marca do temor da separação.

Milner (1969) relata o caso de uma mulher esquizóide, cuja ameaça de enlouquecimento era vivida de forma intensa em qualquer acontecimento pelo qual passasse; Susan, assim nomeada por Milner, após sete anos de análise passou a garatujar inúmeros desenhos durante o processo analítico e suas expressões no papel constituíam um intermediário flexível (p. 30), exterior a Susan, por meio do qual sedimentava a si mesma, a conduzia ao mundo simbólico e tornara a análise realmente possível.

Como revelam esses pacientes, podemos considerar que tanto as inscrições gráficas quanto a escrita não apenas trazem à superfície o rico mundo interno de doentes graves como os psicóticos, em especial os paranóicos, mas estão entranhadas na própria estrutura desses pacientes.

\section{A escrita no caso de Lia}

Ao entrar na sala do ambulatório, Lia, como a chamaremos, apresentou-se como Estela Vassoler, uma jornalista que se dedicava a entrevistar pessoas comuns na rua. Como a analista soube mais tarde, tratava-se de uma personagem, figurada em um de seus romances, que de fictícia tornou-se real. O corpo e a mente de Lia ganharam a densidade daquilo que havia sido escrito, em outro tempo, no suporte de um papel. No tempo da sessão, Lia gravava "a entrevista” que fazia comigo e imediatamente buscava ouvir as vozes que não eram senão ruídos. Deixar-me entrevistar por aquela jornalista foi fundamental para o desenrolar do jogo transferencial, a partir do qual o trabalho psicanalítico se iniciou.

Além de Vassoler, existiam outros personagens - "pessoas fora dela" como o Peter, um pintor famoso, leitor e amigo fiel de sua escrita, e um outro não-nomeado que a aguilhoava e exigia de Lia a execução da sentença de morte de uma vizinha, sua perseguidora, pois esta havia ligado a vida da paciente em uma rede da internet e o mundo todo sabia de seus segredos.

Mais que uma relação psicanalítica, esse primeiro movimento transferencial pode ser tomado como uma situação psicanalítica, pois, na homologia entre esta e o lugar psíquico, figura-se uma construção, uma instauração de um sítio virtual no qual o psíquico mostra-se à superfície (Fédida, 1991, p. 138-9). Nesse sentido, o lugar da situação psicanalítica é o de uma espacialidade como "projeção de uma extensão” (p. 336), numa referência às notas finais realizadas por Freud em 1938 sobre sua concepção do aparelho psíquico. 
Em torno da inscrição "Estela Vassoler" a situação psicanalítica se movimentará em direção a um outro lugar, qual seja, como se verá, o de dar voz, lendo para Lia, à imagem que se fez presente nos primeiros momentos da situação analítica.

Assim, ao nomearmos este ensaio como "Do delirante ao ficcional: um estudo sobre a situação psicanalítica em um caso de paranóia”, consideramos o tratamento de Lia como uma transformação e construção de lugares (Fédida, 1991, p. 118) nos quais a escrita, em constante movimento, deslocava-se e, permeada pela sonoridade da voz de um outro na transferência, veio a ser concebida no terreno da ficção.

O caso de Lia: a palavra que se inscreve no corpo

Diante do inusitado que as primeiras entrevistas nos trouxe, deparamo-nos, então, com uma primeira questão: por que a escrita, tão essencial à vida de Lia, não fora suficiente para conter o desdobramento de seus conteúdos psicóticos? Formulando de uma outra forma, por que, à primeira vista, sua escrita deixava muito mais marcas de ser um veneno do que um remédio (Derrida, 1997) para aquilo que latejava em seu interior e que acabou por explodir em seu delírio paranóico?

No tempo vivido em seu delírio paranóico, isolada em seu quarto, Lia ouvia apenas as vozes de seus personagens e algumas delas a observavam sem trégua e tudo sabiam sobre ela. Desde o artigo de Freud (1911) sobre o Presidente Schreber sabe-se que, na gramática amorosa do paranóico, a pulsão do olhar cumpre um papel fundamental. Ao lado dela, a pulsão da voz sonoriza o olhar superegóico que tudo vê. Assoun considera que essas duas pulsões atravessam a clínica freudiana naquilo que passa pelo olho, que constitui o olhar, que cruza com a voz, com o que se escuta - de si e do outro - e sublinha que, em Lacan, o olhar e a voz são promovidos a "objetos pulsionais no mesmo nível dos objetos paradigmáticos freudianos - oral, anal e fálico” (1999, p. 11-2). Anzieu, em suas reflexões sobre a formação do Eu-pele através dos envelopes psíquicos - dados pelas sensações corporais, pelo tocar, pelo olhar, pelo cheirar, pelo escutar e emitir um som, pelo sonhar, pelo escrever - atribui ao espelho sonoro um estatuto mais precoce que aquele visual, tão importante para a concepção lacaniana do psiquismo infantil. Para esse autor, o primeiro espaço psíquico é dado pelo espaço sonoro, e considera que a condição para que esse espelho sonoro, seguido pelo visual, seja estruturante para o eu depende de a mãe exprimir ao bebê alguma coisa que diga respeito às primeiras qualidades psíquicas vividas pelo então nascente bebê, alguma coisa dela e dele (1989, p. 214-5). 


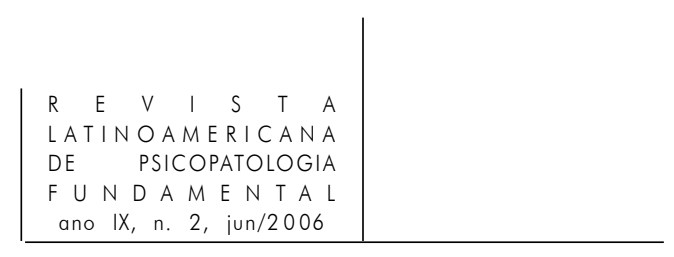

No caso de Lia, por meio das construções pictóricas e escritas realizadas no decorrer do tratamento, pudemos considerar que a voz materna muito deixou a desejar para que pudesse ser um espelho sonoro estruturante para a paciente. A escrita foi sua tentativa de tecer um invólucro psíquico na fenda (Freud, 1924, p. 191) estrutural que lhe restou daquelas primeiras relações objetais. Com a escrita, Lia buscava a voz que lhe faltava. Ou ainda, buscava a palavra que nunca existiu.

Tímida e hermeticamente fechada em seu quarto, muitas vezes Lia viu-se a si mesma sem voz; não porque tivesse sido tomada pela afonia, como na histeria, mas porque acometida por uma inibição da pulsão vocal, desde sempre viu estrangulada sua possibilidade de falar, de dar voz ao que dela brotava. O inquietante mudo fez-se presente em vários momentos do tratamento e, dentre eles, destacamos aquele no qual o canto da cigarra foi o contraponto para o gélido silêncio; fez-se também presente naquilo que havia de esquisito entre a escrita e a fala:

Eu não tinha voz, era muito tímida, já disse a você que meu problema sempre foi o de comunicação. Até que um dia, lá pelo meio dos anos 80 - foi antes do colégio - alguns professores passaram a elogiar minhas redações, poesias e pequenos contos. Nunca me senti tão feliz em toda minha vida e eles me deram o sonho de ser escritora. Mas aí, foi esquisito, porque aí eu não precisava mais me forçar a falar. Só escrevia. Escrevendo, eu tinha voz...

Voz de sonoridade muda que tingia as folhas em branco ou o quadro-negro quando, secretamente, chegava sempre mais cedo na sala de aula e lá deixava ora um pensamento instantâneo, ora uma poesia, ora uma piada obscena. Todos liam, mas não sabiam a quem atribuir o escrito.

Lia não era afônica como a "Dora" de Freud (1905). Seu mutismo era de outra ordem. A procura do espelho sonoro estruturante a levou a escutar as vozes da alucinação. Como observa Cabas, esse objeto - a voz - impõe-se de maneira brutal nos fenômenos psicóticos. (1988, p. 11)

A voz que se escuta é imantada de um real (para o psicótico, ela é o real) que dá ao paranóico a convicção inabalável de um outro que o persegue, e a projeção, no sentido psicanalítico (expressa no eu não o amo, eu o odeio: ele me odeia, ele me persegue), "é um mecanismo que faz voltar de fora o que está preso na Verwerfung, ou seja, o que foi posto fora da simbolização geral que estrutura o sujeito”. (Lacan, 1953, p. 52)

A forma de escrita de Lia não era a de uma escrita louca, pois nela as palavras não se apresentavam retorcidas e incompreensíveis à maneira de neologismos, mas nem por isso deixou de enlouquecê-la. Assim, a palavra, em seus romances, perde sua qualidade metafórica e simbolizante e ganha o 


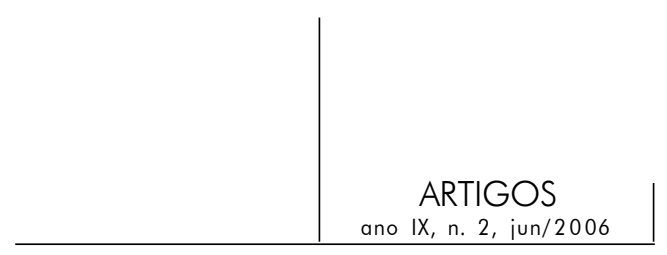

revestimento corporal de uma realidade que ela passa a viver, delirando. Frente a isto, levantamos a questão de que poderíamos equiparar seu mundo literário, tal qual ela viveu, ao tratamento dado às palavras na psicose - de serem tomadas como coisa. Nesse caso, como na regressão do processo de sonhar, há uma ocupação libidinal na “representação da palavra de objetos”, ou ainda, na psicose “as palavras são tomadas como coisas”. (Freud, 1915, p. 52-8)

Leclaire, partindo de sua clínica, construiu uma metapsicologia sobre as relações das palavras do psicótico com o corpo e, para ele, a peculiaridade da organização psicótica está na ausência da clivagem entre o literal e o corpo. A palavra é literalmente tomada como um corpo erógeno e “permanece verdadeiramente colada ao corpo” (1969, p. 140). A palavra, tomada ao pé da letra, perde sua função de "anticorpo" e, em vez de instaurar uma alteridade para o sujeito por meio de uma diferença de uma marca impressa, acaba por aprisionálo como corpo: “... na psicose, tudo se passa como se esta função 'autre’ da letra estivesse recuperada no nível do corpo, anulando a clivagem da própria alteridade” (ibid., p. 143).

Tanto como o herói de $A$ rosa púrpura do Cairo $^{1}$ não sabia que era apenas um personagem criado pela mente de uma dona de casa, cujo vazio a levava a assistir inumeráveis vezes ao mesmo filme, Estela Vassoler, a personagem, não sabia que resultava da criação de Lia. Vá(s)-só-ler e Lia entranham-se uma na outra, e criador e criatura tornaram-se um só. Lia, sonhando ser Vassoler, trouxe seu velho gravador para me entrevistar. Afetada pela personagem, Lia passou a carregá-la em seu corpo e em sua mente: ela é aquela cujo mundo é o das letras, aquela que lê, ou, na fala de Lia, “meu mundo é o literário”. Como o Autor, personagem de Lispector (1994, p. 73) em “Um sopro de vida”, ao reconhecer que por estar cuidando muito da vida de Ângela, a personagem, escreve que virou uma abstração de si mesmo.

O significante "Vassoler” ecoou, enquanto pensamento de transferência (Gori, 1998, p. 50), na situação analítica da primeira entrevista, e veio a criar um ponto de liga para que as afinidades eletivas da transferência pudessem ser efetivadas. Vassoler ressoa como Vá-só-ler e, como tal, engendra um desejo de que aquilo que movia a pena de Lia pudesse ser lido e ouvido. É interessante salientar que a marca deste significante tomou a corporeidade da própria paciente: ela se apresentava como Vassoler e endereçava este significante, num certo sentido, visual, a quem estava diante dela para ser “entrevistada”. Nessa franca eclosão de sua psicose, seu desejo se presentificava como o próprio significante, porém descarnado de qualquer significação simbólica, pois Lia passava ao largo de um deslize de fala e, de forma peculiar à psicose, como Freud bem definiu ao

1. Filme de Woody Allen, da década de 1980. 


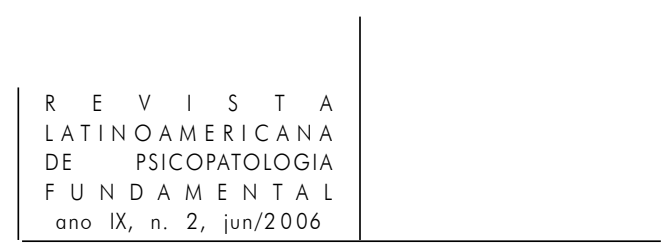

dizer que aí as palavras são tomadas como representação de coisa, apresentavase na concretude corpórea de Vassoler.

\section{O olhar e a voz na situação psicanalítica}

Entrelaçada às primeiras sessões com Lia, e por razões desconhecidas na época, minha memória me conduziu a um jovem paciente a quem, por um ano, pude atender em um hospital público para doentes mentais. Desde criança, José sofrera várias internações psiquiátricas. Esquizofrênico, excluído de qualquer convívio com outros pacientes, e recluso em seu mundo autista, seus doces olhos verdes não refletiam senão uma grande violência que o levara àquele isolamento e à contenção para dormir, por meio de amarras físicas. No estado em que se encontrava, sua fala era escassa e permanecia grande tempo andando em círculos. Um caminhar sem fim deixava um rastro imaginário e continha-o em seu interior. A hora diária em que me dedicava a permanecer a seu lado perdia-se em brumas. Minha presença não existia para ele. Num momento determinado, em uma freqüência muito baixa e suave para não assustá-lo, em ritmo de acalanto, a voz da analista entoou esta canção:

$$
\begin{aligned}
& \text {... alguém cantando longe daqui, } \\
& \text { alguém cantando longe, longe (...) } \\
& \text { A voz de um certo alguém que canta } \\
& \text { Como que pra ninguém }(. . .)^{2}
\end{aligned}
$$

Como nos primeiros instantes não houvera nenhuma explosão de violência, tampouco se desmoronara seu frágil e pequeno mundo, continuei a cantar um pouquinho mais alto e a sonoridade de minha voz atravessou a linha imaginária desenhada no chão pelo seu caminhar. A voz murmurada, que de longe ele ouvira, interrompeu seu andar e o fez parar. Naquele dia, imóvel, ele escutou aquele acalanto imemorial repetidas vezes. Mas ainda não existia nenhum olhar. Nos dias seguintes, o canto vindo de longe transportava a voz de alguém e continuava a suspender temporariamente seu andar louco. Certa hora, seus olhos foram tocados pela voz cantante e ganharam vida. Havia um olhar no lugar do nada. Esboçou um sorriso de criança, apontou-me com o indicador e voltou à sua antiga caminhada. Mas ela já não era a mesma. Tocado pelo acalanto, nos dias seguintes, o olhar de José procurava desenhar no cimento frio da sala uma outra circunferência por sobre a qual caminhara. Por instantes, repetidamente, seu olhar encontrava-se

2. Caetano Veloso. Tribute. Alguém cantando. 


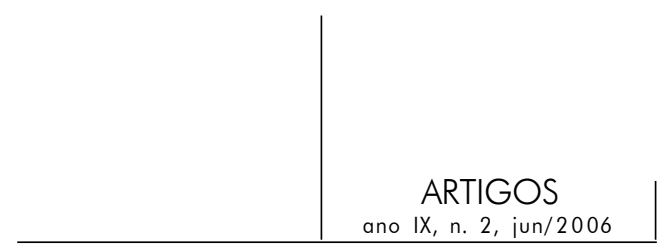

com o olhar daquela que, imóvel, no mesmo lugar em que se colocara da primeira vez, pôs-se a cantar. Num balé sorrateiro, o mapa traçado no chão pelo andar de José teve seus domínios ampliados e abarcou, devagarinho, o corpo daquela voz cantante que, de distante, tornou-se próxima. Um fio de voz pôde-se ouvir e, estendendo um braço do qual pendia seus farrapos, pronunciou uma palavra: "Bolacha”. E em seguida, "me dá uma bolacha".

A lembrança dessa cena clínica, na qual o canto imprimia uma diferença não só em seu caminhar cristalizado como em seu olhar, que passou a encontrar o olhar do outro, atravessou o espaço psicanalítico de Lia. Não se pode esquecer que as primeiras entrevistas com a paciente foram marcadas pelas gravações que ela fazia das vozes da analista e dela própria. Nesse palco, apresentaram-se seus primeiros movimentos transferenciais. Ela ensejava capturar, concretamente, através de um artefato - o gravador - a voz que desaparecia com o vento.

As duas cenas, a de José e a das primeiras entrevistas com Lia, temporalmente distantes, mas tão próximas pelo movimento clínico que elas evocam, determinaram o caminho da clínica com a paciente.

Como bem aponta Fédida, uma poderosa ferramenta no trabalho terapêutico com psicóticos, instituída desde o início nas primeiras entrevistas, é a “simetrização imaginária” (1991, p. 23) - contraponto à dissimetria da relação terapêutica com neuróticos - na qual "o analista torna-se um personagem da cena do delírio". O lugar da analista como o de uma personagem a ser entrevistada pela "jornalista”, criada pelo delírio de Lia, evoca as pegadas deixadas por Gradiva na pele de Zoe Bertgang. A realidade desta, que "brilha ao andar", torna rediviva aquela soterrada em Pompéia e, nesta transfiguração de uma a outra, reside o "tratamento psíquico" administrado por Zoe, através do qual Hanold liberta-se de seu delírio (Freud, 1980, p. 44).

O paradigma de Gradiva, presente nas reflexões posteriores a respeito das primeiras entrevistas com Lia, ressalta o lugar possível em que a analista poderia ter se colocado na cena montada por Lia, com seu gravador a tiracolo. Zoe, diante das dificuldades que Hanold lhe colocava em suas andanças por Pompéia, teve que ser muitas vezes bastante inventiva para, num ponto duplo, fazer-se de Gradiva e ao mesmo tempo tratar do delírio do arqueólogo.

Contudo, no caso de Lia, tanto a "gente comum" como a famosa jornalista Estela Vassoler, entrevistadora daquela, tiveram uma existência curta de algumas semanas. Permeado pela medicação antipsicótica, ${ }^{3}$ gradualmente, o delírio de Lia cedeu e, em seu lugar, restou o nada.

3. Paralelo ao trabalho psicanalítico realizado no serviço público, a paciente era também acompanhada pelo ambulatório de psiquiatria. 


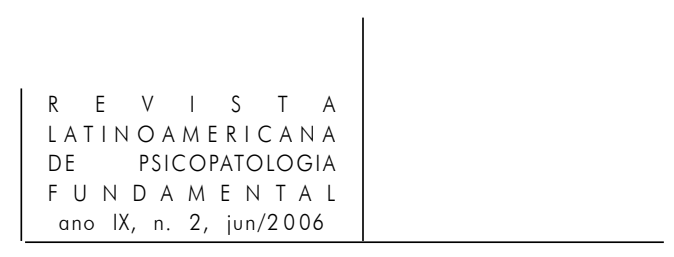

Diverso do delírio de Hanold, no qual Zoe lhe deixava pequenas pistas da realidade, da qual o arqueólogo havia se apartado, neste caso clínico a incidência quase cirúrgica da medicação retirou de Lia a única forma de investimento possível - o delírio - devolvendo-a a uma realidade que não fazia o menor sentido para ela, depositando uma sensação de que tudo havia sido devastado.

Porém, no rescaldo desse mundo que foi por terra, restaram alguns fragmentos. No suporte imaginário de sua escrita não só seus personagens tornaram-se reais. Os contornos, bem como a voz da "gente comum", a quem ela entrevistava em nossos primeiros encontros, perduraram na passagem para outra realidade, sem o delírio. Nesse rescaldo, ao lado das impressões mudas de sua escrita, "o objeto-voz e o objeto-olhar" (Alberti, 1999, p. 7) foram lugares nos quais Lia alojou seu vazio. Não mais entrevistando uma personagem, mas se interrogando, frente à realidade aterrorizante na qual se via, ela perguntava à analista: "Foi tudo criado dentro da minha cabeça? As pessoas, elas não existem? E suas vozes? Eu inventei tudo?”. Seu olhar interrogativo buscava no olhar da analista um ancoradouro, mas, nesse momento de perplexidade, perdia-se no infinito e Lia mergulhou num profundo mutismo.

Em seu segundo andamento, grandes momentos de silêncio delimitaram o espaço da transferência de Lia ao tratamento e o nortearam para uma determinada direção. Num tempo muito posterior a este, ela me escreveu uma carta e aí dizia “... meu corpo é um templo, é o lugar para estar em contato com minhas idéias”. Este corpo-templo, naquele momento de esvaziamento, precisava de um lugar de silêncio quase sagrado para se instalar. Em outra carta, ela escreve:

Lembra-se, uma vez, no ambulatório, em que você me deixou ficar em silêncio durante o tempo todo em que estivemos juntas? E ao fundo, ouvia-se uma cigarra lá fora? E da história da formiga e da cigarra? Pareço a cigarra em meio a muitas formigas. Só que estas formigas nunca me dariam abrigo, nem apreciariam minhas artes... agradeço por aquele silêncio que me disse muitas coisas.

Nunca saberemos o que o silêncio efetivamente lhe disse no interior de seu templo, mas, para quem, a vida toda, viu-se imersa em uma solidão avassaladora, às vezes arredada por personagens imaginados, o sentimento de estar-junto (com a voz e o olhar) com alguém que escutava seu silêncio talvez tenha sido uma experiência inaugural, para ela e para o tratamento. Então, naquele pequeno espaço da sala de atendimento do ambulatório, ouvia-se, silenciosamente, a cigarra a cantar lá dentro, em seu corpo-templo. Esse segundo movimento, no qual sua transferência ao tratamento se alojou, pode ser nomeado como uma passagem da explosão de seu surto psicótico, que perdurou alguns meses, a um lugar no qual as vozes que zuniam fora dela encontraram um espaço dentro dela; e, fora, no espaço de transferência. E agora já não mais barulhentas, mas silenciosas. 
Naquele espaço transferencial no qual Lia pedia o silêncio, adentrou, a princípio, de forma tímida, aquilo que ela nomeara na carta referida como "minhas artes”. Assim, aos poucos, um terceiro movimento foi roubando a cena. Marcado pelo dia em que, quase um ano depois da primeira entrevista, Lia entrou na sala com dois imensos volumes de um romance escrito por ela; a analista, tomada de surpresa, veio a descobrir que muitos dos personagens ali presentes, como Peter e Estela Vassoler, figuraram em seu delírio.

Permeada pelo momento anterior de silêncios intensos, a cena psicoterápica passou a ser animada por momentos de produção escrita, às vezes de uma única frase na qual Lia esboçava seu vazio, às vezes de um poema, às vezes de um conto no qual brotavam personagens que tomavam forma na cena psicanalítica.

Nesse terceiro movimento delineou-se, paulatinamente, um outro lugar de transferência à analista. Semelhante àquele do canto com o paciente esquizofrênico, num dado instante passei a ler em voz alta para Lia. Ora eu fazia a leitura de seus escritos, ora eu escutava o que ela mesma lia.

A emergência de um leitor em seu tratamento levou-nos a perguntar sobre o estatuto que ele e sua ação - a leitura, a voz - teriam tanto para a efetivação do enlace transferencial como para a estabilização de metáfora delirante, uma leitura que, talvez, ressignificasse aquela voz que, na primeira entrevista, Lia queria escutar no gravador.

Um olhar de fora sobre as coisas imaginadas e escritas num outro tempo, acompanhado por uma fala - a viva voz de alguém que é de todos e de ninguém, e que lê o imaginado em seu templo-corpo - criou possibilidades para que nesse templo se inscrevesse uma indelével marca d'água de um outro dela mesma - uma escrita fictícia. No espaço analítico, entre o que se projeta de sua escrita e o que se projeta da leitura em voz alta, construiu-se uma efígie nova de si própria.

Tomamos toda forma de expressão de Lia como subjétil (Derrida, 1998, p. 23), pois isso que, como um projétil, penetra e deixa suas marcas, implica o movimento de ejetar algo do sujeito e lançá-lo numa superfície que se permite atravessar (o suporte material, o papel, a tela, a memória). Assim, consideramos como escrita da paciente não apenas suas poesias, cartas e romances, mas também seus traços esboçados em desenhos e pinturas, bem como tiras de quadrinhos, os quais quase sempre são acompanhados de alguma referência escrita, pois, em suas palavras, eles pedem para serem escritos.

Mas não apenas a produção de Lia pode ser tomada como um subjétil. A nosso ver, a situação psicanalítica na qual a transferência de Lia se efetivara pode também ser vista como tal, no qual ela se esboçava e, inesgotavelmente, escrevia, escrevia, escrevia e se reescrevia. Esse lugar virtual, o da situação psicanalítica, constituiu-se como um subjétil no qual, e sobre o qual, a linguagem escritural de Lia se projetava. 


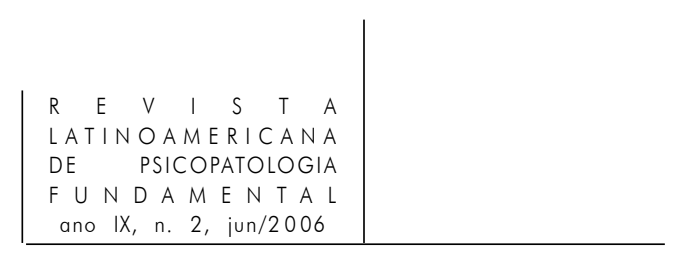

No nicho da situação analítica, a sonoridade da leitura da analista fazia contraponto aos pensamentos escritos em seus desenhos, às suas poesias, às histórias inventadas, à narrativa escrita a respeito de seu processo delirante. A voz que dá suporte à sua criação é também um subjétil que inaugura nela o diferente, o estranho tão familiar dela mesma e no qual se reconhece sem se confundir. A situação psicanalítica é um espaço no qual ela pode fantasiar e sonhar, por vezes perder-se em brumas, mas tendo nas mãos um fio de escrita "sonora" que a ligava ao outro e a tirava do labirinto recoberto pelo espelho de mil faces.

Assim, um segundo propósito deslocou a primeira questão levantada no início deste ensaio. Ao lado dela - por que sua escrita não bastou para evitar uma ruptura psicótica? - uma outra questão, a do lugar da voz e a do leitor no tratamento, foi tomando vulto. A relação entre a escrita de Lia, o leitor e a voz invocada na leitura acabou por roubar a cena, e a resposta à primeira pergunta parece encontrar seu lugar no interior da última.

\section{A leitura transformando a escrita}

Em seu artigo $O$ ego e o id, Freud retomou suas idéias a respeito das inscrições psíquicas, tratadas por ele desde suas cartas a Fliess. Nesse artigo, ele considerou as representações verbais pré-conscientes como traços de memória, portanto, como uma forma de escrita, e, então, escreveu: "E a natureza desses traços mnêmicos está em ser "resíduos de uma palavra que um dia foi ouvida" (1923, p. 33-4).

Nesse sentido, para Derrida, “... a palavra falada não escapa de ser também, originariamente, uma escritura como diferença entre espaços” (1995, p. 211). Aliás, parece ser a partir dessas marcas de espaçamento temporal articuladas na palavra que a esta se confere a possibilidade de ser uma representação simbólica daquilo que era antes apenas coisa. "A temporalização supõe a possibilidade simbólica; e toda síntese simbólica, antes mesmo de cair num espaço 'exterior' a ela, comporta em si o espaçamento como diferença” (ibid.).

No caso de Lia, as imagens impressas no papel remontam tanto à escrita inconsciente quanto à palavra (a língua) com a qual ela se expressa. Aqui, nosso interesse se volta especialmente para esse último ponto. Consideramos que a leitura - visual e oral -, tanto dela quanto minha, com suas pontuações e entonações, trouxe modificações em sua escritura, das quais se abriu uma possibilidade de subjetivação.

Essa química de palavras, lidas e realocadas umas em relação às outras durante o processo da situação psicanalítica, deixou pegadas na criação de Lia de forma a arredá-la para longe do caminho, já conhecido, da loucura paranóica. 
Reescrevendo seu delírio num outro lugar - o da situação analítica - Lia fez sua própria travessia. Se a escrita de Schreber é um relato vivo do delírio e tudo que lá está é tomado como real pelo autor, a escrita de Lia sobre seu delírio, diversa da do primeiro, é, em seu próprio dizer, a lembrança de um sonho.

Essa travessia pela escrita (Bartucci, 2001, p. 14) constituiu-se o lugar de enfrentamento com seus fantasmas: em Ponto de encontro, livro no qual reanimou sua experiência delirante, prefigurou a encruzilhada entre o real e o ficcional. ${ }^{4}$ À medida que escrevia cada capítulo, estes eram rearranjados pela leitura na situação analítica. Nessa escrita, Peter, personagem do delírio, dispõe-se a ser $o$ leitor para Lia.

O ponto de encontro da letra de Lia é o ponto no qual se constrói a alteridade ficcional expressa na indagação final de sua travessia: “Peter, você está aí?”; esta pergunta traz a seu palco imaginário a incerteza, a dúvida, a possibilidade de existência e, como tal, evoca também a não-existência. Há aí um toque fundamental que faz a diferença em relação à paranóia pois, nesta a certeza é um bem inalienável do sujeito, presente em momentos diversos no delírio de Lia. Peter, do ponto de encontro, esta lembrança onírica do delírio, é um contraponto à voz imponderável, a que tudo via e que escutava todos os segredos de Lia, controlando-a como na "rede da internet" e não lhe deixando desvão algum para a dúvida.

Derrida, ao evocar a metáfora da máquina de escrever retratada no bloco mágico, levanta uma questão inovadora: o suporte material exterior determina e altera a impressão da memória arquivada? Sua argumentação para essa questão funda-se nas novas formas de comunicação e impressão, impensáveis há vinte anos. O pensamento deste autor comporta a tese segundo a qual a técnica de impressão, seja ela qual for, não apenas é um meio através do qual se arquiva em memória, mas que ela, a técnica, determina aquilo que será arquivado desta e não daquela maneira. $\mathrm{O}$ que cada um vive a partir daquilo que foi arquivado é diretamente proporcional à forma como se arquiva. Nas palavras de Derrida: "Não se vive mais da mesma maneira aquilo que não se arquiva da mesma maneira" (2001, p. 31).

A partir do material literário, poético, plástico (pinturas e desenhos), que Lia trazia para as sessões e de sua relação com uma possível transformação subjetiva, a partir das leituras conjuntas que fazíamos nesse espaço transferencial, consideramos que a materialidade desse espaço de leitura - a voz do leitor - efetua uma metamorfose em sua forma subjetiva de se inscrever, distinta daquela que

4. Lia elaborou a capa do livro e imprimiu nela o nome "Ponto de encontro", na vertical e na horizontal, de modo a formar uma encruzilhada. 


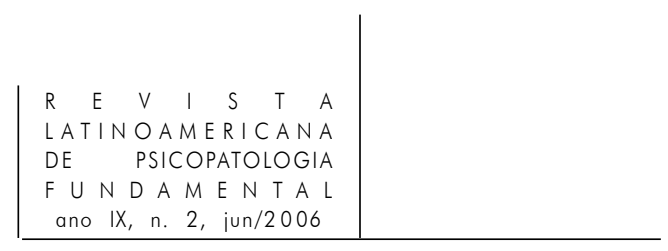

a levou ao delírio paranóico. Se concordarmos com Derrida, podemos dizer que a técnica de impressão parece ter mudado desde o momento em que a leitura dos escritos de Lia, pela analista, passou a redimensionar aquilo que a paciente escutava anteriormente. A forma de se inscrever parece mudar à medida que essas vozes inscritas em si mesmas ganham o espaço da transferência.

\section{Conclusão}

Ao resgatarmos da teoria freudiana o modo peculiar com o qual o psicótico lida com a linguagem - trata a palavra como se fosse coisa -, visamos assinalar que na clínica da psicose é fundamental que não se perca de vista este postulado metapsicológico. A partir dos lugares tomados pela linguagem-coisa "Estela Vassoler" a situação analítica se instaurou. A materialidade da voz de um outro sobre os escritos da paciente vai ao encontro desse postulado psicanalítico. A relevância do leitor, no tratamento de Lia, deve então ser situada no interior do estatuto que agora atribuímos à voz no espaço da situação psicanalítica: o da leitura na qual se contempla a da pulsão da voz e a do olhar. Distante de um leitor que sugerisse o perfil da razão e do logos, o olhar do leitor dos escritos de Lia veste o manto da pulsão pura da voz, da melodia, do vocalise que embala uma criança.

Vassoler era a tentativa de Lia de escapar de sua tão familiar anomia, mas jamais poderia ter sido um heterônimo para ela. Se, como aponta Silva Jr., a realidade é posta em questão na ficção pessoana, de forma $a$ tornar a realidade ela mesma ficcional (2003, p. 73), no caso de nossa paciente, ao fundir a alteridade consigo própria, a ficção virou realidade.

Dos poros de seu corpo transpirava uma outra realidade: a cerca simbólica em torno de seu bosque de imaginação era muito tênue e de seus vãos esparramava uma Vassoler, personificada no próprio corpo de Lia. No delírio, Vassoler é Lia. O espaço do corpo e o espaço da letra não são mais cindidos por uma diferença e na confusão desse espaço absoluto (Leclaire, 1991, p. 142) encontrava sua clausura psicótica. Nesse corpo pulsional enraizou-se, literalmente, a palavra "Estela Vassoler". Seu corpo parecia ser seu próprio suporte de escrita. Com isto queremos dizer que, em primeiro lugar, ao delirar ser uma outra, é no corpo que ela se reinscreve, literalmente sendo Vassoler, aquilo que o suporte do papel não pode conter, de forma a que a fusão entre a identidade e a alteridade é escancarada neste caso clínico.

Permeada pela voz de um outro fora dela, ao longo do tratamento, Lia passa a assinar suas pinturas e desenhos, não com seu próprio sobrenome, mas com 
uma invenção retirada dele e que se aproxima, em sua sonoridade, com a idéia de "destaque”. Interessante é que nesse outro momento ela comenta: "É só um nome, não sou eu”.

Mas o ponto culminante desse processo de transformação de sua escrita em sua relação com a leitura no tratamento foi o da produção de Ponto de encontro, livro autobiográfico sobre sua experiência delirante. Aí, a alteridade constituída não era mais a da certeza delirante, mas a daquela que instituía a dúvida, expressa na interrogação final do livro: Peter, você está aí? Nesse livro, Lia confere a Peter o lugar do leitor dileto, pois ele não tinha o dom de escrever como ela. Ao término deste ensaio não poderíamos deixar de assinalar que há um deslocamento de Estela Vassoler para Peter: Este, lá, vá só ler.

A singularidade do tratamento de Lia reside em fazer da situação analítica um lugar de confluência para sua escrita, sua pintura, seus desenhos, seus recortes, colagens e costuras com a leitura - o olhar e a voz -, os nacos de palavra que a alimentam. Aí, a materialidade da voz do leitor - que lê com os olhos e com a boca - traz à cena analítica uma alteridade diversa daquela que aparece nas vozes que escutava em seu estado de delírio. O enlace com o leitor-analista assegura a Lia uma certa estabilidade naquelas páginas que, em outro tempo, tremeram e fizeram saltar seus personagens para a realidade delirante. Assim, ao desenrolar do processo analítico, a leitura trouxe transformações a sua escrita e nela se desvela seu caminho de subjetivação.

Trilhando o caminho da clínica, é de se pensar que a escritura de Lia - e aqui, por influência de Derrida, marcadamente reconhecida por nós - sofre uma transformação subjetiva ao transitar do espaço isolado de seu quarto ao espaço do consultório, ao espaço do ateliê de desenho e pintura que passou a freqüentar, ao espaço da oficina de poesia e literatura, e de costura do Serviço de Saúde para o qual foi encaminhada. Esses espaços transformam aquilo que, em outro momento, nomeamos como "sua forma particular de se inscrever no mundo" e de se subjetivar. A atmosfera desses espaços, povoada de formas, cores e cheiros, imprime-se em sua escritura e deixa aí aromas diversos, como aquele do café, retratado em uma de suas poesias: "Desculpe pelo furto do cheiro/ De café feitinho nesta hora/ Da sua casa.../ Mas sou poeta". Por aquilo que nela se inscreve, a partir desses espaços, Lia encontra o direito de se apropriar de algo que é de todos e de ninguém, exalado pelo cheiro do café. Capturada pelo que emana desses espaços, ela também se inscreve neles e se enlaça no espaço social.

Na arquitetura da situação analítica, a relação entre seu corpo de escrita no corpo em que inscrevia Vassoler - e os suportes (folha de papel, tela, tecido), nos quais ela continuou a se inscrever, sofreu modificações. O olhar da analista, para o suporte no qual ela se inscrevia, sessão a sessão, parecia transformar o olhar do "objeto louco" em olhar do "objeto-trauma” (Green, 1988, p. 155). 


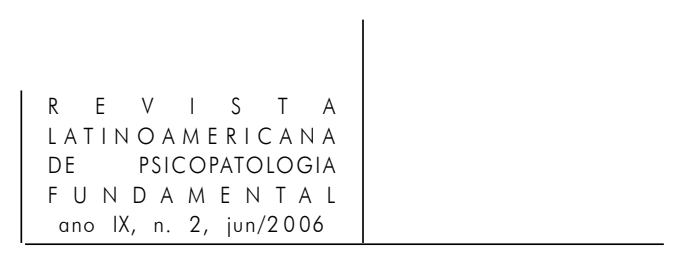

O olhar, a voz, o toque, o cheiro do objeto-trauma formam sulcos no psiquismo infantil, os quais fazem a diferença entre ser sujeito e ser nada. Ao escutar a sonoridade da voz que lia seus escritos (estes, equivalentes a seu corpo), Lia se encantava com um narcisismo inaudito. $\mathrm{O}$ olhar da analista sobre seus escritos teve para Lia uma equivalência simbólica ao daquele que, ao tocar a criança, imprime-lhe uma diferença.

Assim, a ação e a presença de um leitor fora de sua escrita marcam para Lia uma diferença em relação àquela escrita anterior à derrocada na psicose. O leitor - seu olhar e sua voz - construído na situação transferencial na qual Lia pôde desenhar, pintar, escrever e reescrever sua história, foi determinante para não se perder nas brumas de um lago escuro, de uma certa escrita que a envenenava e a "con-fundia" com seus personagens, ou ainda, que não viesse a esfumaçar a linha que separa aquele que escreve e inventa histórias daqueles que são personagens a figurar nessa escrita.

É necessário dizer que, nesse outro momento de vida, seu mundo continua sendo o literário. Porém, Lia tem guardado uma distância de seus personagens, o suficiente para que eles continuem a ser os depositários de seus estados de alma, sem, contudo, transformar o literário em literal - sem tomar o literário ao pé da letra.

A sonoridade da voz - a leitura - no trabalho clínico com Lia implicou, mais que qualquer possibilidade de interpretação, imprimir um rastro, deixar uma marca a partir da qual surge um sopro de vida...

\section{Referências}

AlBeRTI, S. (org.). Autismo e esquizofrenia na clínica da esquize. Rio de Janeiro: Marca D’Água, 1999.

Anzieu, D. O eu-pele. São Paulo: Casa do Psicólogo, 1989.

Assoun, P.-L. O olhar e a voz. Lições psicanalíticas sobre o olhar e a voz. Rio de Janeiro: Companhia de Freud, 1999.

Bartucci, G. (org.). Psicanálise, literatura e estéticas da subjetivação. Rio de Janeiro: Imago, 2001.

Birman, J. (org). Tausk e o aparelho de influenciar na psicose. São Paulo: Escuta, 1990.

CABAs, A. G. A função do falo na loucura. Campinas: Papirus, 1988.

Derrida, J. A escritura e a diferença. São Paulo: Perspectiva, 1995.

A farmácia de Platão. São Paulo: Iluminuras, 1997. 
2001.

Mal de arquivo. Uma impressão freudiana. Rio de Janeiro: Relume-Dumará,

Derrida, J. \& Bergstein, L. Enlouquecer o subjétil. Unesp, 1998.

FÉDIDA, P. Nome, figura e memória. A linguagem na situação psicanalítica. São Paulo: Escuta, 1991.

Freud, S. (1905). Fragmento da análise de um caso de histeria. In: Edição Standard Brasileira das Obras Psicológicas Completas de Sigmund Freud. Rio de Janeiro: Imago. v. VII.

(1907). Delírios e sonhos na Gradiva de Jensen. In: Edição Standard Brasileira das Obras Psicológicas Completas de Sigmund Freud. Rio de Janeiro: Imago, 1980. v. IX.

(1911). Notas psicanalíticas sobre um relato autobiográfico de um caso de paranóia. In: Edição Standard Brasileira das Obras Psicológicas Completas de Sigmund Freud. Rio de Janeiro: Imago, 1980. v. XII.

(1923). O ego e o id. In: Edição Standard Brasileira das Obras Psicológicas Completas de Sigmund Freud. Rio de Janeiro: Imago, 1980. v. XIX.

(1924). Neurose e psicose. In: Edição Standard Brasileira das Obras Psicológicas Completas de Sigmund Freud. Rio de Janeiro: Imago, 1980. v. XIX.

(1925). Uma nota sobre o "Bloco mágico”. In: Edição Standard Brasileira das Obras Psicológicas Completas de Sigmund Freud. Rio de Janeiro: Imago, 1980. v. XX.

(1938). Achados, idéias, problemas. In: Edição Standard Brasileira das Obras Psicológicas Completas de Sigmund Freud. Rio de Janeiro: Imago, 1980. v. XXIII.

Green, A. Narcisismo de vida, narcisismo de morte. São Paulo: Escuta, 1988.

Lacan, J. O seminário. Livro 3. As psicoses. Rio de Janeiro: Jorge Zahar, 1985.

Da psicose paranóica em suas relações com a personalidade. Rio de Janeiro: Forense-Universitária, 1987. p. 175.

LeCLaire, S. As palavras do psicótico. In: Katz, Chaim S. (org.). Psicose, uma leitura psicanalítica. São Paulo: Escuta, 1991.

Manguel, A. No bosque do espelho. São Paulo: Companhia das Letras, 2000.

MiLneR, M. The Hands of the Living God: An Account of a Psychoanalytic Treatment. London: Hogarth, 1969.

Schnitzler, A. Meu amigo Ypsilon. In: Contos de amor e morte. São Paulo: Companhia das Letras, 1987.

SiLVA, Jr. O lugar de ninguém: ausência e linguagem na situação analítica. Percurso, n. n. 31, v. 2 / n. 32, v. 1, 2003-2004.

WinnicotT, D. W. O brincar e a realidade. Rio de Janeiro: Imago, 1979. 


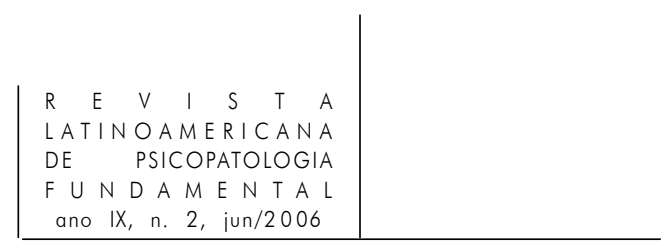

\section{Resumos}

Este ensayo es un estudio psicoanalítico a respecto de Lia, paranoica, artista en tiempo integral, que al urdir sus historias, vio la fina hebra que separa la ficción de la realidad esfumarse en su acto de escrita. Escritora de novelas y poesías Lia también pinta sobre cualquier superficie que se le presente. Consideraremos que su paranoia no puede ser separada de su producción literaria y gráfica, pues ellas están extremamente fundidas una con la otra. Así, el tratamiento psicoanalítico realizado con esta paciente devino precisamente de aquello que constituye su paranoia: su producción escrita y artística. Durante el desarrollo de la situación analítica su escrita se ve transformada por la lectura del otro fuera de ella y, en este nicho, Lia pudo construir una forma diferente de subjetivación.

Palabras claves: Escrita, lectura, paranoia, psicoanálisis

Cet essai décrit une étude psychanalytique sur Lia, paranoïaque, artiste à plein temps qui, en tissant ses histoires, se rend compte que la ligne qui sépare la fiction de la réalité de sa production écrite a perdu ses contours bien définis. Lia n'écrit pas seulement des romans et des poésies, mais elle peint aussi sur toute sorte de supports qu'elle rencontre. Nous présupposons que la paranoïa ne peut pas être séparée de sa 262 production littéraire et graphique, étant donné qu'elles sont liées entre elles. Ainsi, le traitement psychanalytique de cette patiente découle précisément de ce qui constitue sa paranoïa: sa production écrite et artistique. Pendant le développement de la situation analytique, sa production écrite est transformée par la lecture d'un autre en dehors d'elle-même et, dans cette niche, Lia réussit à construire une forme différente de subjectivation.

Mots clés: Production écrite, lecture, paranoïa, psychanalyse

This article consists of a psychoanalytic study on a paranoiac patient named Lia. She is a full-time artist as well as writer, and, in spinning her tales, she saw the line that separates fiction from reality evaporate as she wrote. Lia produces novels and poems, and paints on any medium she has at hand. We can suppose that her paranoia cannot be separated from her literary and graphic production, since they are so closely interwoven. Therefore, the psychoanalytic treatment with this patient was based specifically on that which constituted her paranoia, namely, her writings and artistic production. As the analytic situation evolved, her writing was transformed by the reading by another outside her. In this niche Lia was able to construct a different form of subjectivation.

Key words: Writing, reading, paranoia, psychoanalysis

Versão inicial recebida em maio de 2005

Aprovado para publicação em setembro de 2005 